\title{
Infarction of a Giant Breast Hamartoma in a Pregnant Patient Mimicking an Inflammatory Breast Cancer
}

\author{
Mahmoud Haj $^{\mathrm{a}} \quad$ Anna Chernihovski $^{\mathrm{b}} \quad$ Vera Solomon $^{\mathrm{b}} \quad$ Norman Loberant $^{\mathrm{b}} \quad$ Isaac Cohen $^{\mathrm{c}}$ \\ ${ }^{a}$ Dept. of Ambulatory Surgery, \\ ${ }^{b}$ Dept. of Diagnostic Radiology, \\ ${ }^{c}$ Dept. of Pathology, Western Galilee Hospital, Nahariya, Israel
}

\section{Key Words}

Breast · Hamartoma · Infarction · Pregnancy

\section{Summary}

Background: A giant mass of the breast with discoloration of the overlying skin during pregnancy requires investigation to rule out the possibility of breast malignancy. The aim of this paper is to report a case of rapidly growing hamartoma in a pregnant patient mimicking advanced breast cancer and to discuss the usefulness of sonography and core needle biopsy in the diagnosis. Case Report: A 24-year-old woman in her 16th week of pregnancy presented with a very enlarged and painful breast. The overlying skin was edematous, brown to red, with severely dilated and congested veins. A huge mass was palpated and easily separated from the main breast. Results: Sonography and needle core biopsy were consistent with benign lesion but inadequate to exclude malignancy. At surgery, a giant $(1,600 \mathrm{~g})$ well-defined, ovoid mass was enucleated under general anesthesia. Gross and microscopic sections of this tumor were consistent with hamartoma with a central area of infarction. Clinical and histological features of this tumor are briefly discussed. Conclusion: Inability to exclude malignancy in case of symptomatic giant breast tumor during pregnancy should be an indication for early surgical excision.

\author{
Schlüsselwörter \\ Brust · Hamartoma $\cdot$ Infarkt $\cdot$ Schwangerschaft
}

\section{Zusammenfassung}

Hintergrund: Während der Schwangerschaft auftretende Umfangsvermehrungen der Brust mit farblicher Veränderung der Haut sollten in jedem Fall untersucht werden, um einen bösartigen Tumor auszuschließen. Wir berichten hier von dem Fall eines schnell wachsenden Hamartoms bei einer schwangeren Patientin, welches sich als fortgeschrittenes Mammakarzinom darstellte, und diskutieren den Nutzen von Sonographie und Nadelbiopsie bei der Diagnostik. Fallbericht: Die in der sechzehnten Woche schwangere 24-jährige Frau stellte sich mit einer stark vergrößerten und schmerzhaften Brust in unserer Klinik vor. Die Haut der Brust war ödematös, bräunlichrot gefärbt, mit stark erweiterten und gestauten Venen. Ein großer Tumor war fühlbar und deutlich vom restlichen Brustgewebe abgrenzbar. Ergebnisse: Sonographie und Nadelbiopsie wiesen auf eine gutartige Neoplasie hin, ein malignes Geschehen war jedoch nicht auszuschließen. Unter Vollnarkose wurde ein großer, $1600 \mathrm{~g}$ schwerer, gut abgegrenzter, eiförmiger Tumor entfernt. Die histologische Untersuchung ergab ein Hamartom mit zentralem Infarktbereich. Die klinischen und histologischen Aspekte dieses Tumors werden besprochen. Schlussfolgerung: Falls sich Bösartigkeit eines großen symptomatischen Mammatumors während der Schwangerschaft nicht ausschließen läßt, ist die frühe chirurgische Entfernung gerechtfertigt.

\begin{tabular}{ll}
\hline KARGER & @ 2007 S. Karger GmbH, Freiburg \\
$\begin{array}{l}\text { Fax +49 761 4520714 } \\
\begin{array}{l}\text { E-mail Information@Karger.de } \\
\text { www.karger.com }\end{array}\end{array}$ & Accessible online at: \\
www.karger.com/brc
\end{tabular}




\section{Introduction}

The term hamartoma was introduced by Arrigoni et al. [1] in 1971, to indicate a well-defined, encapsulated breast tumor composed of abnormal blending of normal breast tissue components, and lacking a single distinctive pathological appearance. Although the incidence of hamartoma has been reported to be $0.1-0.7 \%$, the true incidence is believed to be higher due to increasing use of breast imaging and image-guided biopsies. Breast hamartoma is most frequently discovered in the 4th to 6 th decade, with a reported age range of 5-76 years [3, 4]. This benign tumor may contain coincidental focal epithelial malignancy, including in situ ductal carcinoma, invasive duct carcinoma or invasive lobular carcinoma $[4,5]$. Inflammatory skin reaction associated with a rapidly enlarging breast mass usually is suspicious for breast cancer. Negative core needle biopsy does not essentially exclude focal malignancy. A case of giant breast hamartoma with infarction and inflammatory reaction mimicking breast cancer is presented.

\section{Case Report}

A 24-year-old pregnant woman was referred to our breast clinic because of rapid enlargement of her left breast associated with mastitis-like appearance. There was no history of trauma, fever, family breast cancer or pre-gestational breast disorders or asymmetry. On inspection, her left breast was larger than the right one and showed reddish skin with superficial venous congestion, mimicking inflammatory breast cancer. A huge tender mass was palpated on the lateral aspect of the breast. It was mobile and had a smooth surface. Sonography showed a hypoechoic large homogenous mass with a defined capsule occupying the most of the left breast and displacing the normal gestational breast tissue consistent with benign tumor (fig. 1)

A core needle biopsy showed benign lesion composed of ductal and stromal hyperplasia, with small communicating spaces lined with myofibroblasts consistent with pseudoangiomatous hyperplasia (PASH). 2 weeks later, the patient underwent complete excision of the tumor under general anesthesia at our day hospital. It was easily and completely enucleated, without any significant bleeding. The tumor was lying on the chest wall and occupying the lateral upper and lower quadrants while normal breas tissue was displaced mediocaudally. The post-operative course was uneventful, and 4 months after surgery the left breast looks similar to the right one, except for some residual discoloration and cutaneous venous congestion.

Macroscopic examination showed a very large, well-delineated mass measuring $18 \times 13 \times 8 \mathrm{~cm}$, weighting 1,600 g, composed of fibroelastic tissue with a central dark area representing an infarction (fig. 2). Hematoxylineosin sections showed normal ductal lobular units surrounded by connective tissue with communicating slit-like spaces typical for PASH (figs. $3 \mathrm{~A}$ and B). The dark area showed infarction with coagulation necrosis. Immunohistochemistry showed strong positive nuclear stain for progesterone receptor (fig. $3 \mathrm{C}$ ).

\section{Discussion}

Hamartoma of the breast is an uncommon benign tumor-like nodule that presents as a discrete, encapsulated painless mass.

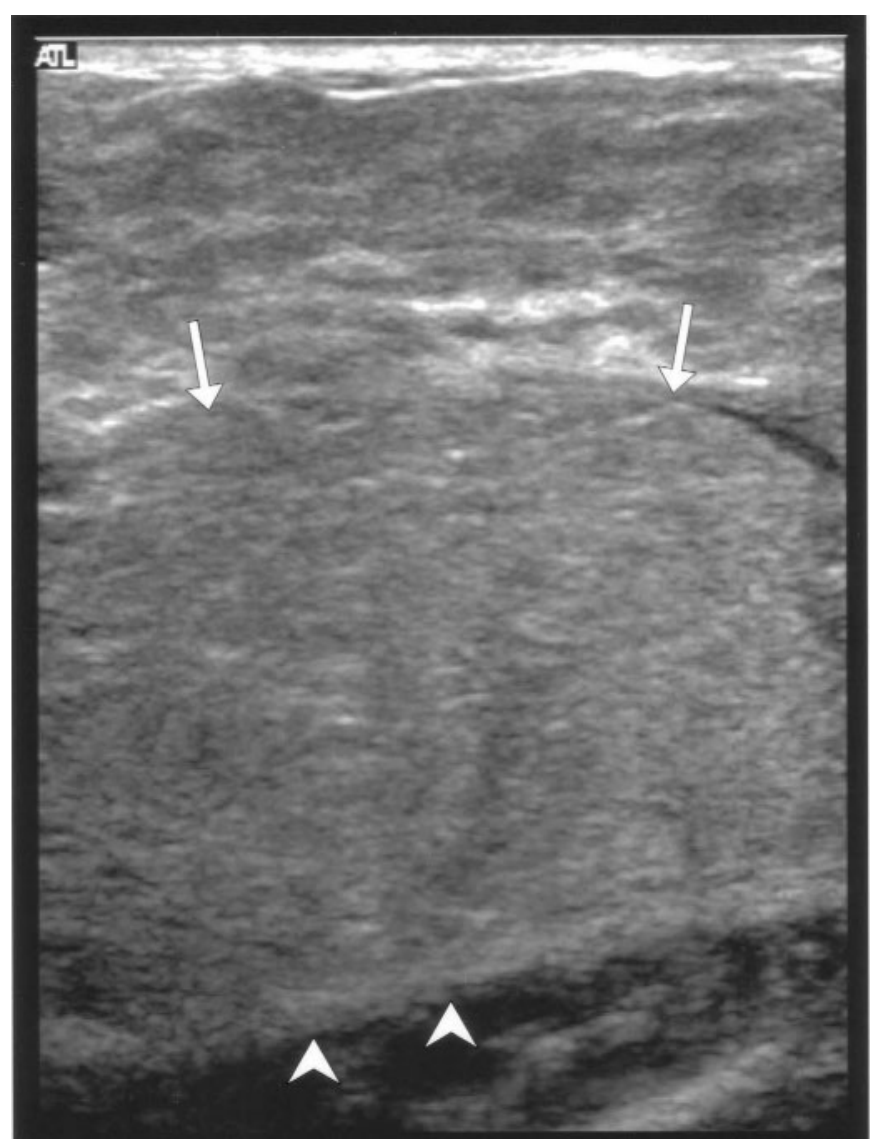

Fig. 1. Sonographic image of the left breast shows a large hypoechoic mass of nearly homogeneous echotexture. The ventral surface abuts the normal glandular tissue (white arrows). The dorsal surface abuts the pectoralis muscle (white arrowheads).

Its pathogenesis is unclear, it might be a result of dysgenesis rather than a true tumor [2].

A case of giant hamartoma of the breast appearing in a 24year-old woman during the first trimester of her first pregnancy is reported. The unique features of this case include central infarction, skin inflammatory-like reaction, and painful, heavy breast. Sonography and core needle biopsy were characteristically benign, although, malignancy within such a large hamartoma cannot be ruled out as it had been reported [4, 5]. Clinically, giant fibroadenoma, lactating adenoma, cystosarcoma phylloides, giant hamartoma, fibrocystic mass, angiosarcoma and inflammatory breast carcinoma are included in the differential diagnosis. These conditions may appear similar on physical examination, but their management is of wide range from conservative follow-up to mastectomy. Hamartomas comprise $3.9-4.8 \%$ of benign breast tumors, while $75 \%$ of all breast tumors in young women are fibroadenomas. Less than $5 \%$ of the fibroadenomas present as giant fibroadenomas defined as a tumor greater than $5 \mathrm{~cm}$ in diameter and weighing more than $500 \mathrm{~g}$ [6]. Rapid growth of a hamartoma during pregnancy may be due to proliferative activity shown by normal breast tissue in reaction to high hormonal levels. Inadequate blood 


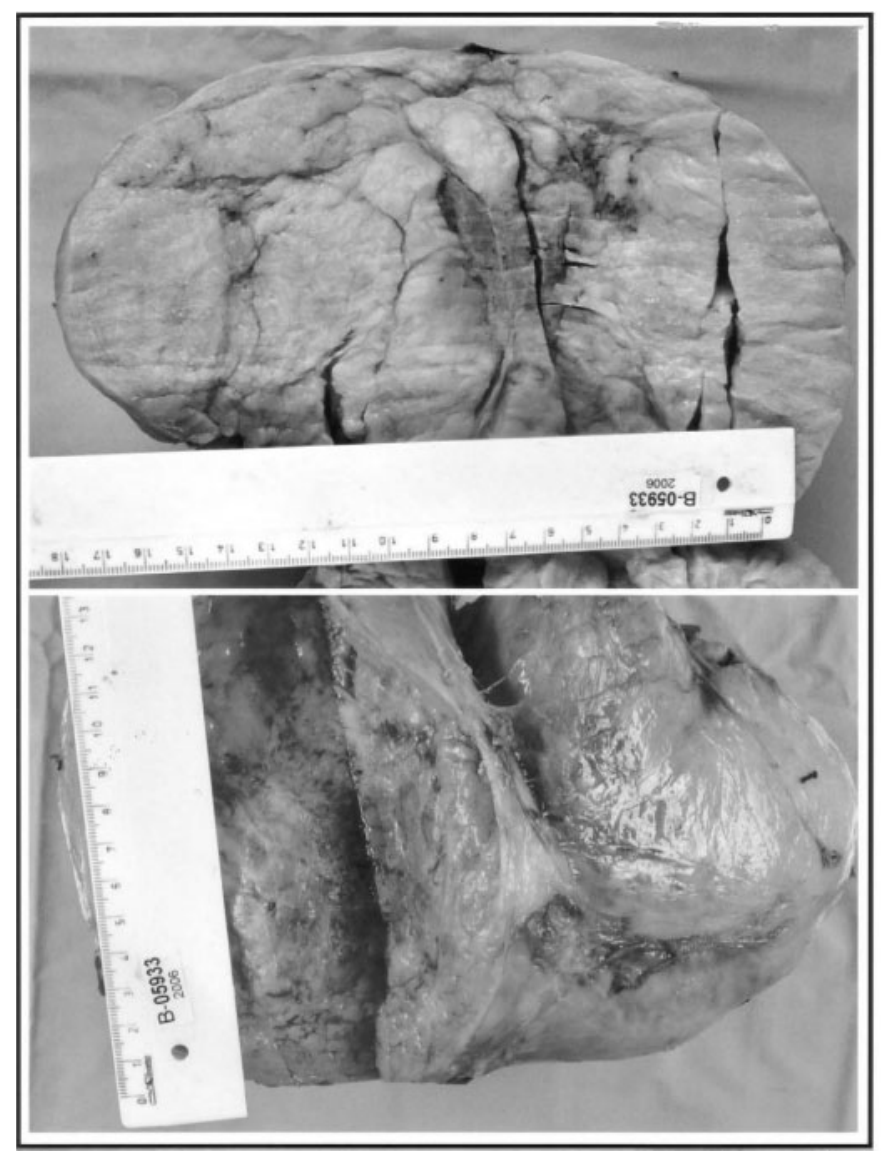

Fig. 2. Macroscopic image of the tumor. Transverse section shows homogeneous fibroelastic tissue with a central dark discoloration representing an area of infarction.

supply or vascular occlusion in a rapidly growing tumor may lead to infarction. Spontaneous infarction of physiological breast tissue or adenoma-fibroadenomas presenting as breast mass during pregnancy is recognized but a rare occurrence [7]. Given the rarity of breast hamartomas in general, its occurrence in pregnant patient as a giant tumor that undergoes spontaneous infarction must be an extremely rare event. Therefore, only few cases of breast hamartoma associated with pregnancy or lactation were reported, one of them being

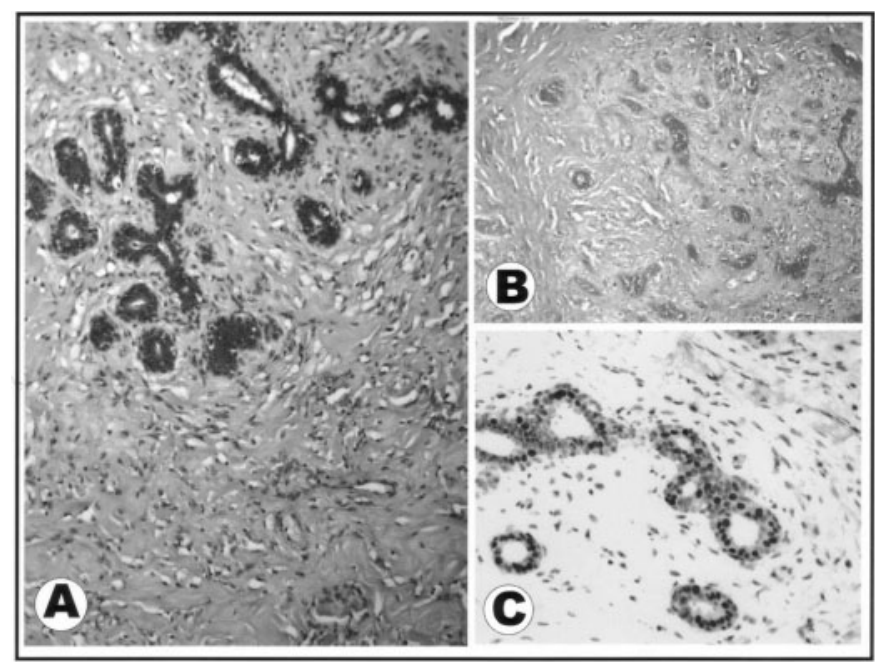

Fig. 3. A $H \& E$ high power and B low power: Microscopically the lesion is composed of normal ductal elements surrounded by connective tissue with communicating slit-like spaces typical of pseudoangiomatous stromal hyperplasia. C Immunohistochemistry showing strong nuclear stain for progesterone receptor.

a giant hamartoma diagnosed in a young postlactational patient but without infarction [8]. To our knowledge this is the first report of giant hamartoma with infarction in the breast of a pregnant woman (a PubMed search using the term 'breast giant hamartoma with infarction in pregnancy' failed to produce any article).

The role of fine needle aspiration and core needle biopsy in making the diagnosis is very limited, since hamartomas do not possess specific diagnostic histological features. Surgical excision is curative, and only a few cases of recurrence have been reported [9]. The presence of pseudo-angiomatous stromal hyperplasia within a hamartoma was found to be a constant observation, although the incidence varies from high $71 \%$ to a low $16-20 \%$ [9]. It was reported that PASH has a hormonal etiology and shows an impressive response to tamoxifen [9-10]. Inability to exclude malignancy in the case of a symptomatic breast tumor during pregnancy should be an indication for early surgical intervention.

\section{References}

1 Arrigoni MG, Dockerty MB, Judd ES: The identification and treatment of mammary hamartoma. Surg Gynecol Obstet 1971;133:577-582.

2 Guray M, Sahin AA: Benign breast diseases: classification, diagnosis, and management. Oncologist 2006;11:435-449.

3 Deshmukh H, Prasad S, Patankar T: A giant vascular hamartoma of the breast in a child. J Postgrad Med 1997:43:50-51.

4 Tse GM, Law BK, Pang LM, Cheung HS: Ductal carcinoma in-situ arising in mammary hamartomas. J Clin Pathol 2002;55:541-542.
5 Breucq C, Verfaillie G, Peradeaens C, Vermeiren B, Stadnik T: Lobular carcinoma located in a breast hamartoma. Breast J 2005;11:508-509.

6 Muttarak M, Chaiwun B: Imaging of giant breast masses with pathological correlation. Singapore Med J 2004;45:132-139.

7 Jimenez JF, Ryals RO, Cohen C: Spontaneous breast infarction associated with pregnancy presenting as a palpable mass. J Surg Oncol 1986;32: 174-178.

8 Weinzweig N, Botts J, Marcus E: Giant hamartoma of the breast in a young postlactational female patient. Plast Reconstr Surg 2001;107:1216-1220.
9 Tse GM, Law BK, Ma TK, Chan AB, Pang LM, Chu WC, Cheung HS: Hamartoma of the breast: a clinicopathological review. J Clin Pathol 2002;55: 951-954.

10 Pruthi S, Reynolds C, Johnson RE, Gisvold JJ: Tamoxifen in the management of pseudoangiomatous stromal hyperplasia. Breast J 2001;7:434-439. 